\title{
Redesain rumah susun tipe 54 di Kelurahan 24 Ilir dan 26 Ilir Palembang, penerapan green architecture pada bangunan dan kawasan
}

\author{
Mirza Hidayat $^{\text {a, }}{ }^{*}$, FX B. Pangarso ${ }^{\text {b }}$, Nurina V.Ayuningtyas a \\ a Program Studi Arsitektur, Fakultas Teknik, Universitas Widya Mataram Yogyakarta \\ b Program Studi Arsitektur, Fakultas Teknik, Universitas Katolik Parahyangan \\ 1 email penulis pertama : mirzahidayat193@gmail.com
}

\begin{tabular}{l}
\hline Informasi artikel \\
\hline Sejarah artikel: \\
Diterima \\
Revisi \\
Dipublikasikan \\
\hline Kata kunci: \\
Redesain \\
Rusun \\
Green Architecture
\end{tabular}

ABSTRAK

Di kota Palembang terdapat hunian yang sudah lama dikenal oleh masyarakat yaitu rumah susun tipe 54 yang berlokasi di kelurahan 24 Ilir dan 26 Ilir, Kecamatan Bukit Kecil, Palembang. Rusun tipe 54 adalah rusun milik Perum Perumnas (Perusahaan Umum Perumahan Nasional) dibangun pada tahun 1981. Rusun tipe 54 adalah rusun sederhana milik (Rusunami), artinya kepemilikan unit ruang hak milik penghuni. Seiring berjalannya waktu dengan sistem kepemilikan, menjadikan rusun ini tampak kumuh dan semerawut karena penghuni dengan keinginannya merubah, mengurangi dan menambah ruang. Pihak pengelola tidak menerapkan peraturan tegas terhadap penghuni rusun karena ruang tersebut adalah hak milik penghuni, karena itu perlunya dibenahi sistem pengelolaan rusun, supaya tidak terulang kembali. Rencana Pemkot dan Perum Perumnas untuk merancang ulang rusun tipe 54 (Redesign), karena tidak layak berada di perkotaan dan tidak layak huni. Pihak Perum perumnas merencanakan rusun bertingkat dengan ketinggian bangunan mencapai 20 lantai, tetapi harus disesuaikan dengan peraturan peruntukkan pada kawasan tersebut. Wilayah perkotaan yang sebagian besar kegiatannya adalah komersil, gedung rusun beserta kawasannya direncanakan menyediakan fasilitas komersil sebagai daya tarik masyarakat terhadap kawasan rusun. Konsep arsitektur yang tepat diterapkan pada rusun yang berada berada di wilayah perkotaan mampu memberikan dampak positif terhadap efek buruk pembangunan, meminimalkan polusi udara yang disebabkan kendaraan bermotor, adanya pengelolaan sampah, adanya pengelolaan air bekas pakai dan hemat energi. Konsep yang mampu menanggulangi permasalahan tersebut adalah konsep green architecture. Rusun yang baru diharapkan keberadaannya dapat memberikan dampak positif bagi lingkungan alam dan masyarakat kota Palembang.

Key word:

Redesign

Village

Green Architecture

\section{ABSTRACT}

In the city of Palembang there are homes that have long been known by the public, namely type 54 flats located in 24 Ilir and 26 Ilir sub-districts, Bukit Kecil District, Palembang. Flat type 54 is a flat owned by Perum Perumnas (National Public Housing Corporation) which was built in 1981. Flat type 54 is a simple flat owned (Flat), meaning ownership of the unit of the property rights of the occupants. Over time with the ownership system, making this apartment look dirty and chaotic because the residents with their desire to change, reduce and increase space. The management does not apply strict rules for the residents of the flat because the space is the property of the residents, therefore it is necessary to improve the flat management system, so that it does not recur. The plan of the City Government and Public Housing of the National Housing Agency to redesign flats of type 54 (Redesign), because they are not fit to be in urban areas and are not livable. Perumnas Perumnas plans to build multi-storey towers with a building height reaching 20 floors, but must be adjusted according to regulations for the area. Urban areas where most of the activities are commercial, flat buildings and their areas are planned to provide commercial facilities as a community attraction to the flat area. Appropriate architectural concepts applied to towers located in urban areas are able to have a positive impact on the adverse effects of development, minimize air pollution caused by motor vehicles, the existence of waste 
management, the management of used water and saving energy. The concept that is able to overcome these problems is the concept of green architecture. The new flats are expected to have a positive impact on the natural environment and the people of Palembang

Copyright (C) 2019 Universitas Widya Mataram Yogyakarta. All Right Reserved

\section{Pendahuluan}

Kota Palembang adalah salah satu kota besar di Indonesia yang sedang mengalami kemajuan dari berbagai sektor yaitu ekonomi, infrastruktur, industri dan pendidikan. Kota Palembang juga menjadi pusat perekonomian di Provinsi Sumatra Selatan. Status sebagai pusat perekonomian mengakibatkan banyak penduduk yang mencari pekerjaan dan menempuh pendidikan di kota Palembang. Kondisi tersebut menjadi penyebab kepadatan penduduk di kota Palembang. Pada tahun 1980-an terbentuknya pemukiman kumuh dan tidak teratur terutama di kelurahan 23 Ilir dan 24 Ilir (Hariadhi. 2017).

Sejarah mencatat bahwa pada tahun 1980- an terjadi kebakaran di pemukiman 23 Ilir dan 24 Ilir yang tidak diketahui penyebabnya. kebakaran tersebut menghanguskan banyak rumah penduduk. Berdasarkan informasi dari Drs. Jonika Ikatama selaku Pimpinan Perum Perumnas (Perusahaan Umum Perumahan Nasional) Kecamatan Bukit Kecil, Palembang rumah susun di bangun sekitar tahun 1981 akibat peristiwa kebakaran tersebut. Pemerintah daerah beserta Perumnas berinisiatif mendirikan Rumah Susun untuk menampung korban kebakaran dan menghindari munculnya daerah pemukiman kumuh, menghindari pembangunan liar yang dilakukan masyarakat dan sekaligus upaya efisiensi penggunaan lahan, karena lokasi kebakaran tersebut tepat berada di pusat kota Palembang. Rumah susun yang dibangun saat itu terdiri dari 3 tipe yaitu 18, 36 dan $54 \mathrm{~m}^{2}$. Pada saat itu rumah susun kurang diminati karena bukan kebiasaan masyarakat Palembang tinggal di rumah susun, tetapi dengan perkembangan zaman rumah susun diminati masyarakat karena lokasinya yang strategis yaitu di pusat kota Palembang. Sebagian besar penghuni rumah susun rata-rata berpenghasilan menengah kebawah yaitu bekerja sebagai pedagang, karyawan, pendidik (Guru), mahasiswa dan lain- lain. Rusun yang di bangun oleh pihak perumnas ini adalah Rusunami (Rumah Susun Sederhana Milik) yang artinya kepemilikan unit ruang adalah hak milik penghuninya.

Rumah susun yang akan dibahas dengan skripsi ini adalah rumah susun tipe 54 di kelurahan 24 ilir dan 26 ilir. Secara arsitektural permasalahan yang muncul saat ini seperti, usia bangunan tergolong tua yang mempengaruhi kualitas kekuatan bahan bangunan, penghuni bebas mengganti warna cat bangunan sehingga terjadi perbedaan warna pada tiap unit, mengganti pintu atau jendela, atap yang sudah rusak, blok no 43 pada lantai 4 yang merupakan bekas kebakaran tidak diperbaiki maupun dihuni kembali, penghuni menjemur pakaian disembarang tempat dapat merusak keindahan tampak bangunan dan penghuni rusun yang menempati lantai dasar menambah ruang 2- 3 meter membangun pada tanah bersama yang tidak sepatutnya menjadi hak milik pribadi. Masalah lingkungan yaitu sering terjadinya banjir karena kurangnya resapan dan banyaknya sampah yang berserakan baik diluar blok rusun maupun di dalam blok rusun, hal ini terjadi karena tidak diterapkannya peraturan penghuni rumah susun oleh pihak pengelola (KPPR. ,2016.).

Kepala badan perencana pembangunan daerah kota Palembang Muhammad Sapri Nungcik, pada hari sabtu 12 sepetember 2015 mengatakan bahwa bangunan rumah susun akan dijadikan semi apartemen, karena rusun yang keberadaannya di tengah kota ini tidak layak huni dilihat dari aspek kebersihan, hygienis, kenyamanan dan keindahan. Rusun semi apartemen ini akan mendukung kebutuhan hunian kota Palembang diwaktu yang akan datang. Pemkot Palembang dan Perum Perumnas (Perusahaan Umum Perumahan Nasional) sudah bersepakat untuk merencanakan rumah susun tipe 54 di kelurahan 24 Ilir dan 26 Ilir menjadi semi apartemen dengan ketinggian mencapai 20 lantai. Marketing manager Perum Perumnas mengatakan bahwa pihaknya juga belum mengetahui bagaimana tindak lanjut rencana akan dijadikan semi apartemen, menunggu sampai ada keputusan dari pemerintah daerah setempat (Rangkuti ,2018). Permasalahan arsitektural, permasalahan lingkungan, permasalahan sosial serta rencana pemerintah kota yang telah dijabarkan pada paragraf diatas dapat disimpulkan perlunya pengajuan merancang ulang rusun tipe 54 dikelurahan 24 Ilir dan 26 Ilir, Palembang. 
Jurnal Arsitektur Pendapa | Universitas Widya Mataram, Yogyakarta

Vol. 2 No. 1 Tahun 2019 | $44-53$

\section{Metode}

Metode yang digunakan dalam pengumpulan data adalah metode studi literatur, metode observasi, metode wawancara dan metode studi banding (Sodik, DKK. ,2015). Data yang didapat dianalisis dan dijadikan dasar ketika proses perencanaan dan perancangan (Sugiyono, 2006).

\section{Hasil dan pembahasan}

Kondisi eksisting rusun Tipe 54, Palembang beserta permasalahan yang sudah di jelaskan pada bab sebelumnya dapat disimpulkan bahwa rusun tersebut tidak layak huni dan tidak layak berada di pusat kota Palembang, sehingga perlu direncanakan dan dirancang ulang kembali (redesign). Rencana pemerintah dan Perum Perumnas dapat dibenarkan. Berikut ini adalah skema proses redesign rusun tipe 54, Palembang.

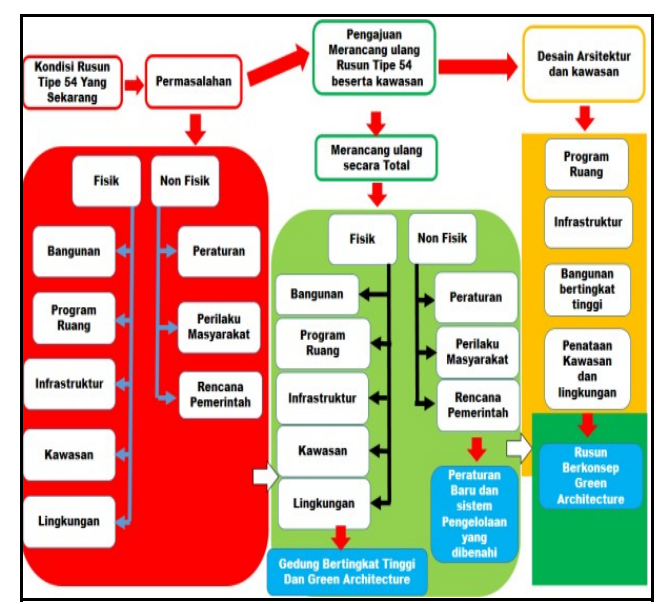

Gambar 1. Skema proses redesign rusun tipe 54 Sumber : Analisa Penulis, 2019

Pembangunan gedung diperkotaan menyebabkan banyak dampak negatif bagi lingkungan, ditambah lagi dengan polusi udara karena asap kendaraan disebut dengan istilah pemanasan global (Yoga. ,2015). Lokasi Rusun yang berada di pusat kota kehadirannya diharapkan dapat meminimalkan dampak buruk akibat pembangunan gedung dan dapat meminimalkan pencemaran udara. Rusun tidak hanya sebagai hunian tetapi memberikan dampak positif terhadap lingkungan sekitanya.

GBC Indonesia (GBCI, 2019) mengeluarkan sistem rating yang dinamakan Greenship. GBCI greenship terbagi atas enam kategori yang terdiri dari: Tepat Guna Lahan - Appropriate Site Development (ASD), Efisiensi dan Konservasi Energi - Energy Efficiency \& Conservation (EEC), Konservasi Air - Water Conservation (WAC), Sumber \& Siklus Material - Material Resources \& Cycle (MRC), Kualitas Udara \& Kenyamanan Udara Dalam Ruang - Indoor Air Health dan Comfort (IHC), Manajemen Lingkungan Bangunan - Building \& Enviroment Management (BEM).

Rusun yang semula hanya menyediakan satu tipe unit hunian, yaitu tipe 54 dengan kondisi yang kumuh (tidak layak huni) akan direncanakan penambahan tipe unit hunian lainnya yaitu tipe 18, tipe 36 dan hunian difabel dalam satu gedung, karena kebutuhan masyarakat dan menambah nilai jual rusun. Kehadiran rusun bertingkat tinggi diharapkan dapat memenuhi kebutuhan hunian untuk masyarakat kota Palembang. Pengaturan zona pada lantai rusun dapat dilihat pada gambar dibawah ini. 


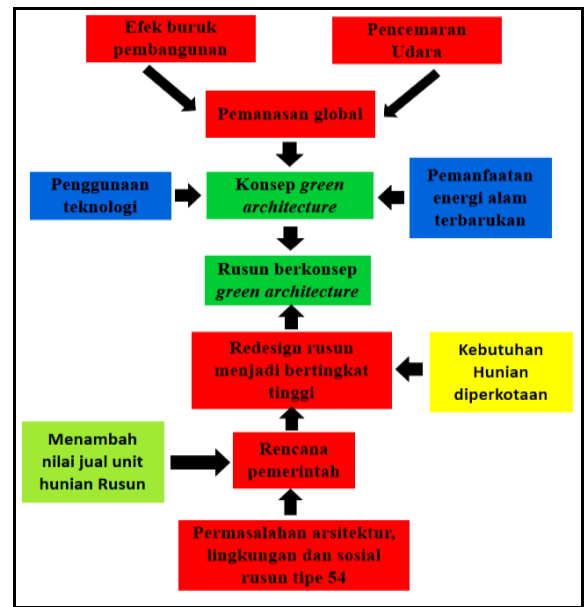

Gambar 2. Skema perencanaan rusun bertingkat tinggi dan penerapan konsep green architecture.

Sumber : Analisa Penulis, 2019

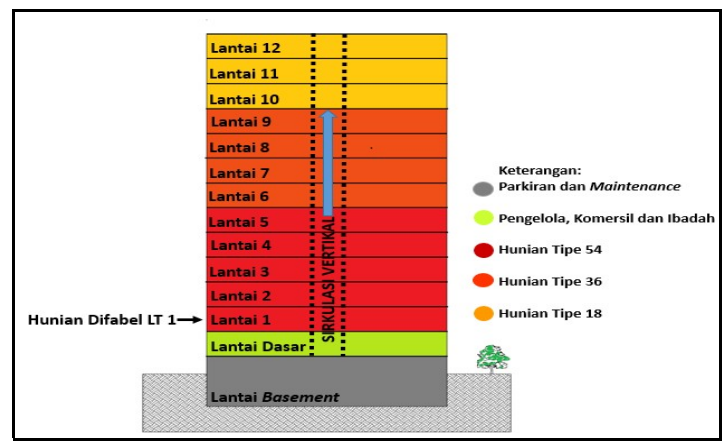

Gambar 3. Zona kegiatan pada lantai rusun

Sumber : Analisa Penulis, 2019

1. Pengolahan Tapak

Penerapan peraturan kawasan pada tapak yaitu GSB (Garis sempadan Bangunan) dan GSS (Garis sempadan sungai), dapat dilihat pada gambar dibawah ini (RTRW. ,2012-2023).

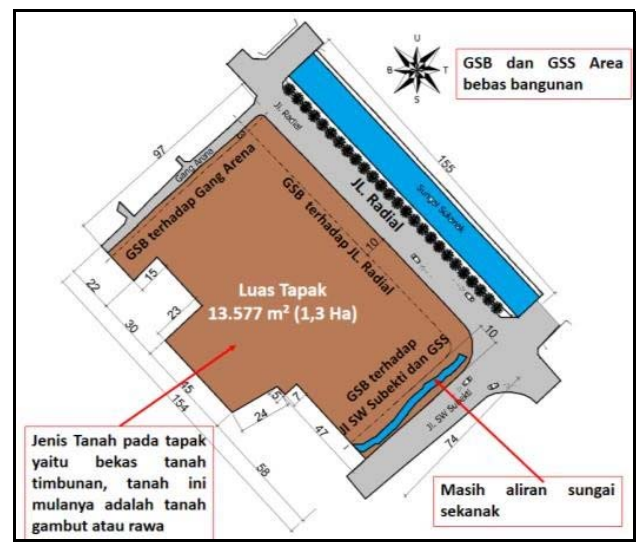

Gambar 4. Penerapan Regulasi GSB, GSS dan Kapasitas tapak

Sumber : Analisa Penulis, 2019 
Jurnal Arsitektur Pendapa | Universitas Widya Mataram, Yogyakarta

Vol. 2 No. 1 Tahun $2019 \mid 44-53$

2. Analisis Bentuk Massa

Bentuk denah hunian vertikal untuk masyarakat menengah ke bawah minimal memenuhi kriteria sebagai berikut (Hendrix Van, DKK. ,2017):

a. Penyusunan unit hunian yang teratur,

b. Mampu memasukkan Pencahayaan alami dan penghawaan alami ke dalam ruang hunian,

c. Tersedianya jemuran pakaian yang tidak merusak pemandangan fasad,

d. Tersedianya ruang bersama untuk penghuni,

e. Tersedianya area bermain yang berdekatan dengan gedung.

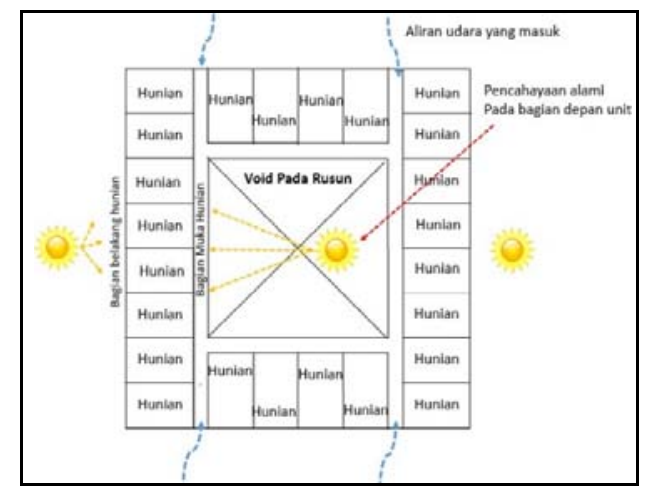

Gambar 5. Bentuk denah rusun Sumber : Analisa Penulis, 2019

3. Tata Ruang Luar

Rencana penataan ruang luar bangunan yaitu berupa penghijauan, pedestrian akses masuk basement, keluar basement, area bermain anak dan parker (PMPU, 2008). Peruntukkan area hijau (tanah) berdasarkan peraturan kawasan minimal 20\% dari total luas lahan (Hakim, 2012), angka minimum area hijau pada site yaitu $2.715,40 \mathrm{~m}^{2}$. Peraturan kawasan yang diterapkan memenuhi persyaratan green architecture GBCI pada kategori Tepat Guna Lahan - Appropriate Site Development (ASD). Rencana penataan ruang dapat dilihat pada gambar dibawah ini

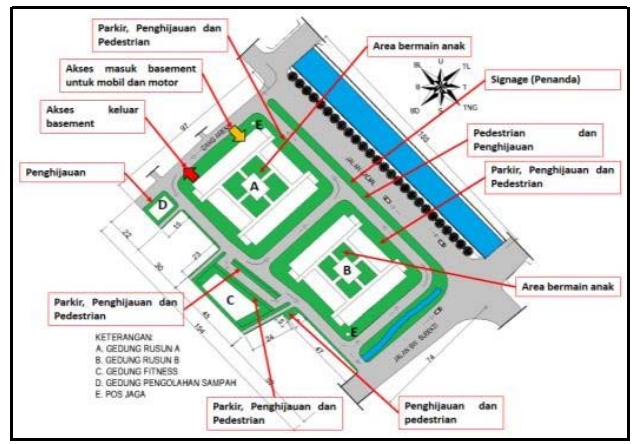

Gambar 6. Rencana tata ruang luar Sumber : Analisa Penulis, 2019 


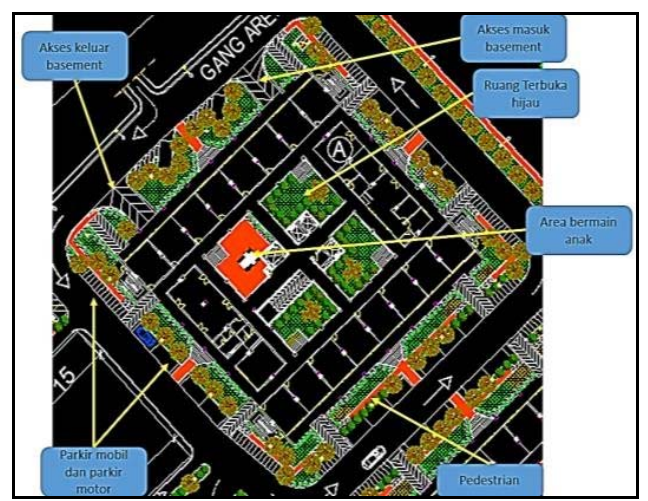

Gambar 7. Penataan ruang luar 1 pada kawasan rusun Sumber : Analisa Penulis, 2019

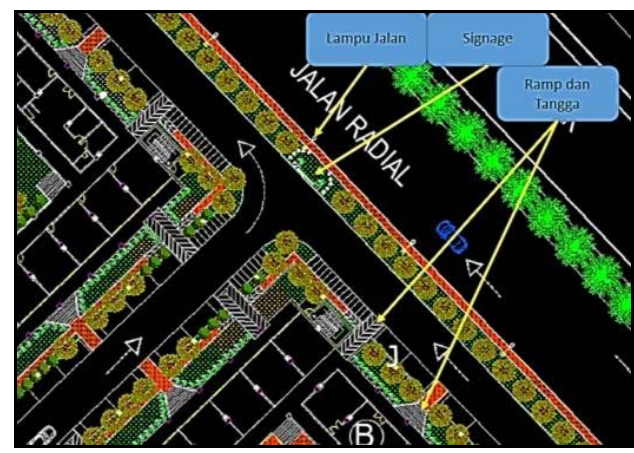

Gambar 8. Penataan ruang luar 2 pada kawasan rusun Sumber : Analisa Penulis, 2019

Pada ruang luar rusun sebagian bahan bangunan yang digunakan adalah material bekas rusun tipe 54 (rusun sebelumnya), bahan yang digunakan yaitu batako. Penggunaan batako untuk batas parkir dan list pedestrian, penggunaan material bekas pada ruang luar rusun telah memenuhi syarat green architecture GBCI pada kategori sumber \& siklus material Material Resources \& Cycle (MRC).

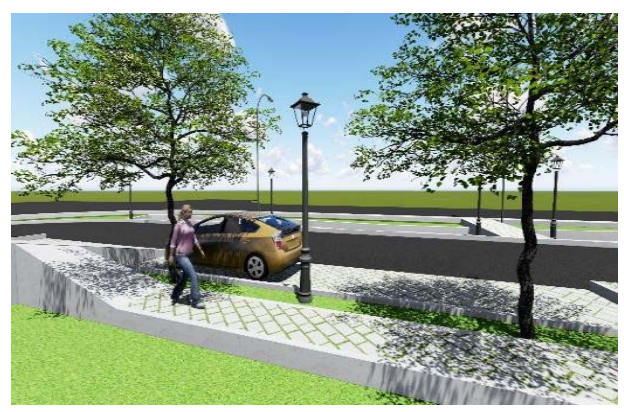

Gambar 9. Parkir

Sumber : Analisa Penulis, 2019 


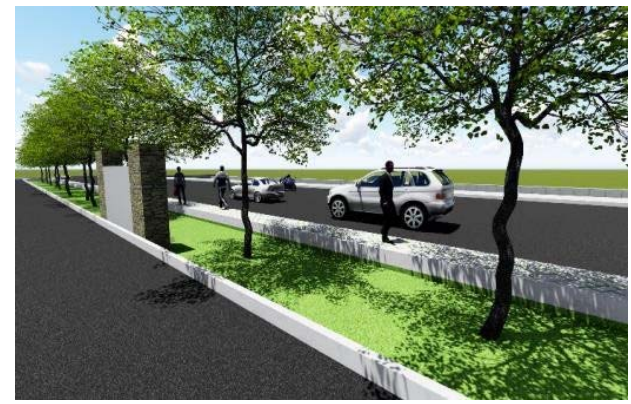

Gambar 10. Jalur pejalan kaki

Sumber : Analisa Penulis, 2019

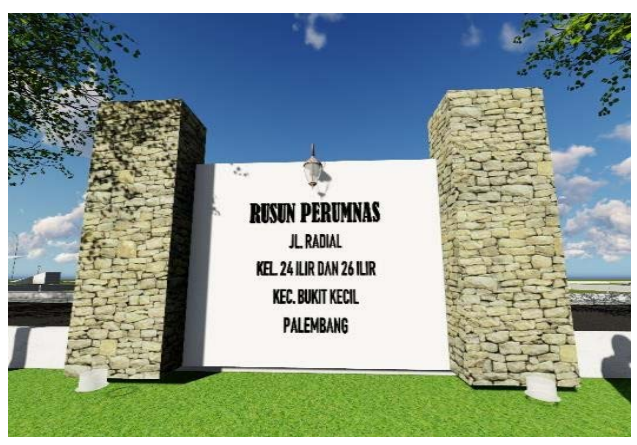

Gambar 11. Signage pada rusun

Sumber : Analisa Penulis, 2019

Rumah susun juga dihuni oleh anak- anak, kebiasaan anak-anak khusunya umur 4 sampai 7 tahun yaitu bermain bersama, karena itu perlunya disediakan area bermain anak yang aman. Tempat bermain anak terletak pada bagian void rusun, ruang void adalah ruang yang aman dan terkontrol oleh orang tua. Gambar berikut ini adalah area bermain bermain anak di rusun.

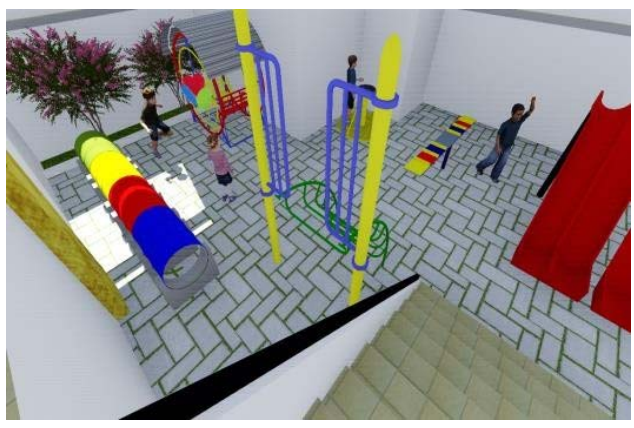

Gambar 12. Area bermain anak

Sumber : Analisa Penulis, 2019

\section{Konsep Massa}

Kawasan rusun terdapat 6 massa bangunan yaitu 2 gedung rusun, 2 pos jaga, satu gedung fitness dan satu gedung pengelolaan sampah. Pada gedung rusun unit huniannya menggunakan pencahayan alami dan penghawaan alami (Avesta, DKK. ,2017) untuk memenuhi persyaratan green architecture GBCI pada kategori Efisiensi dan Konservasi Energi - Energy Efficiency \& Conservation (EEC), bentuk unit hunian dapat dilihat pada gambar dibawah ini. 


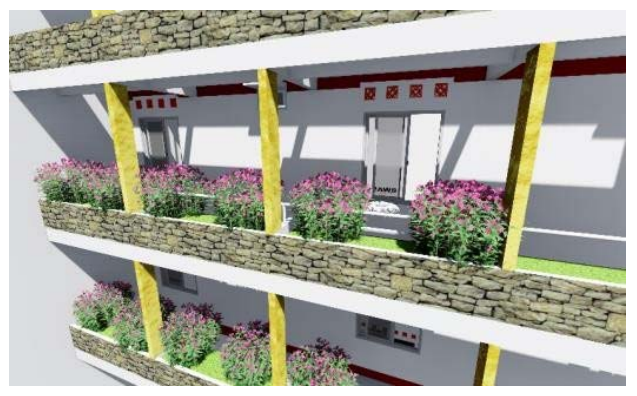

Gambar 13. Pencahayaan alami dan penghawaan alami Sumber : Analisa Penulis, 2019

Pada bagian depan unit terdapat bak tanaman (wall garden) yang berfungsi sebagai pelindung dinding dari sinar matahari dan tanaman sebagai penyejuk udara dalam ruang. Kesejukkan dalam ruang memenuhi persyaratan green architecture GBCI pada kategori Kenyamanan Udara Dalam Ruang Indoor Air Health dan Comfort (IHC).

Pada bagian atap rusun terdapat green roof yang ditanami rumput gajah mini (sebagai groundcover) dan bunga azalea, penanaman bunga azalea membentuk sebuah pola yang berfungsi sebagai pengarah ke area santai. Green roof dan green wall memenuhi persyaratan green architecture pada kategori Tepat Guna Lahan - Appropriate Site Development (ASD), dapat dilihat pada gambar berikut ini

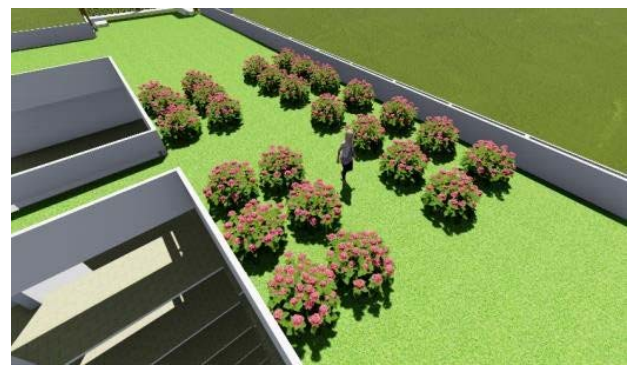

Gambar 14. Pola penanaman bunga azalea

Sumber : Analisa Penulis, 2019

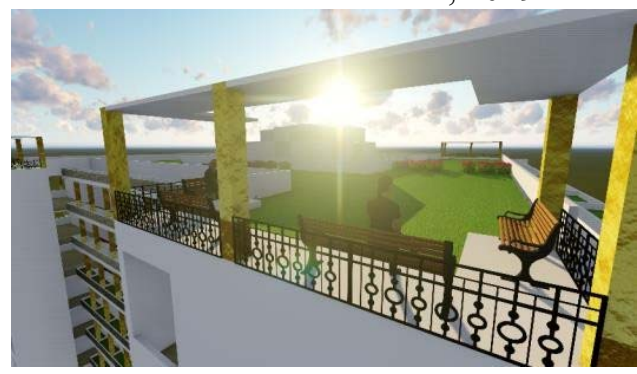

Gambar 15. Area santai pada green roof Sumber : Analisa Penulis, 2019

Penyiraman menggunakan air bekas pakai untuk menyiram tanaman memenuhi kategori memenuhi persyaratan green architecture pada Konservasi Air - Water Conservation (WAC). 
Warna rusun yang mendominasi adalah warna putih, pemilihan warna putih karena warna ini lebih cerah dan tidak menyerap panas, berefek pada kenyamanan penghuni di dalam ruang. Selain warna putih rusun juga menggunakan warna emas dan warna merah yang melambangkan kejayaan.

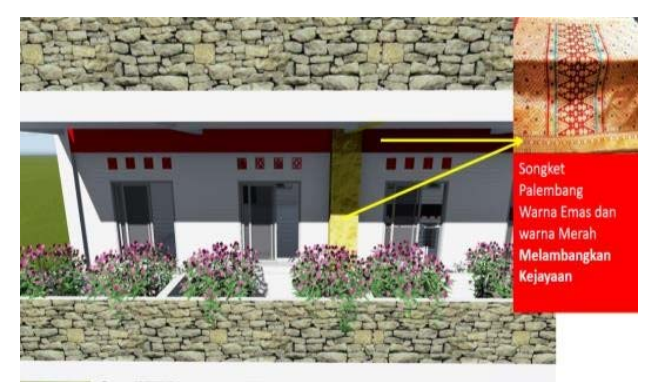

Gambar 16. Penerapan warna emas dan warna merah pada rusun Sumber : Analisa Penulis, 2019

Rusun memiliki area void, pada area tersebut terdapat koridor yang merupakan sirkulasi menuju ke unit hunian. Pada koridor terdapat tempat menjemur pakaian yang telah disediakan untuk masing- masing unit. Jemuran ini terbuat dari bahan besi hollow yang dirangkai sedemikian rupa. Pada bagian bawah terdapat lempengan fiber yang berfungsi untuk menahan tetesan air pakaian penghuni yang berada di atasnya.

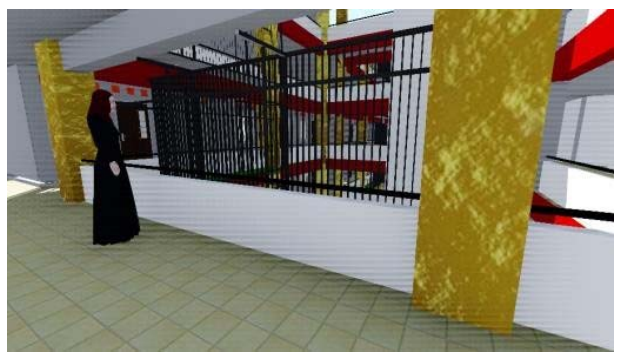

Gambar 17. Tampak koridor rusun

Sumber : Analisa Penulis, 2019

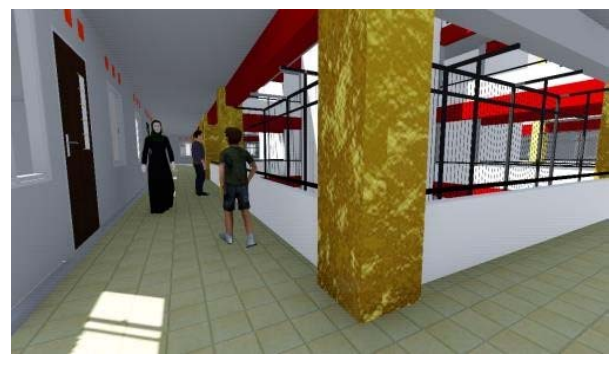

Gambar 18. Tempat menjemur pakaian

Sumber : Analisa Penulis, 2019 


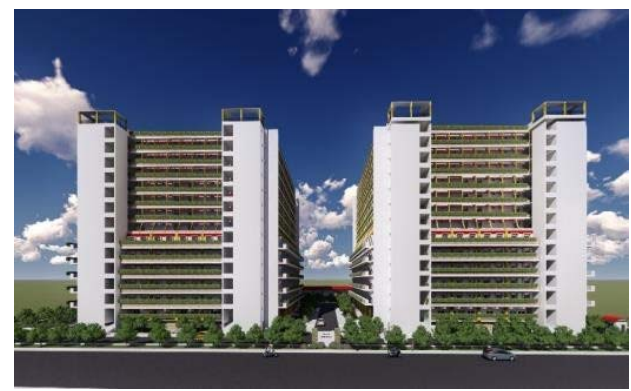

Gambar 19. Tampak depan rusun A dan rusun B Sumber : Analisa Penulis, 2019

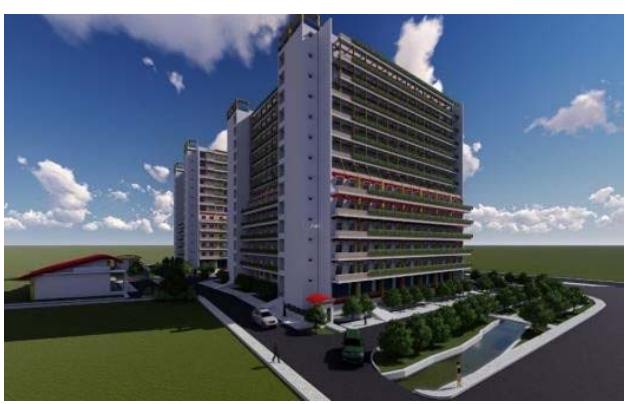

Gambar 20. Perspektif gedung rusun Sumber : Analisa Penulis, 2019

Pengelolaan sampah pada kawasan rusun menyediakan 5 jenis warna kotak sampah, pada gedung rusun disediakan tabung yang terbuat dari bahan fiber serupa dengan warna tempat sampah yang menjulang dari lantai bawah sampai lantai atas. Tabung sampah di letakkan di depan koridor, penghuni tidak perlu turun ke lantai bawah dan petugas sampah tidak perlu naik ke atas. memenuhi kategori memenuhi persyaratan green architecture pada Manajemen Lingkungan Bangunan - Building \& Enviroment Management (BEM). Berikut ini adalah warna tempat sampah beserta jenis sampah

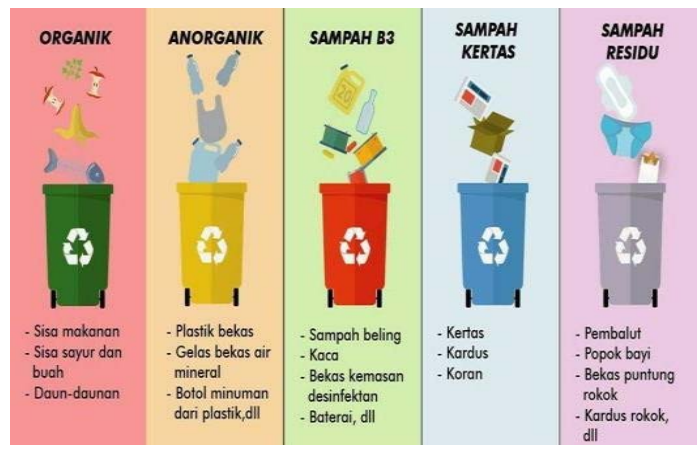

$\begin{array}{ll}\text { Gambar 21. Warna kotak sampah } \\ \text { Sumber: } & \text { https://www.facebook.com/EarthHour Surabaya }\end{array}$ 
Jurnal Arsitektur Pendapa | Universitas Widya Mataram, Yogyakarta

Vol. 2 No. 1 Tahun $2019 \mid 44-53$

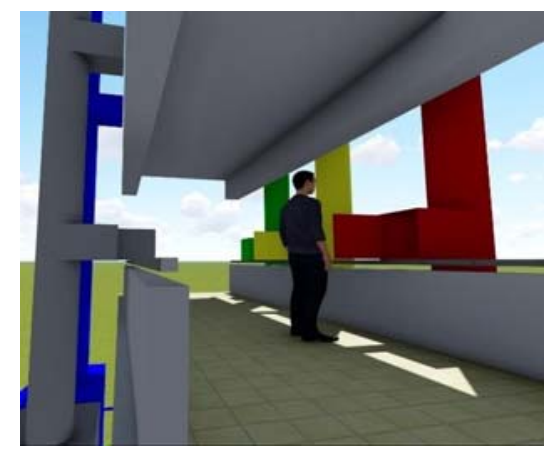

Gambar 22. Pembuangan sampah pada rusun

Sumber : Analisa Penulis, 2019

Bentuk massa bangunan pengelolaan sampah menyesuaikan dengan lingkungan luar, karena adanya ruang pemilahan sampah, pembuatan pupuk dan pada bagian depan diletakkan bak sampah yang berhubungan dengan lingkungan luar, berikut ini adalah bentuk massa pengelolaan sampah.

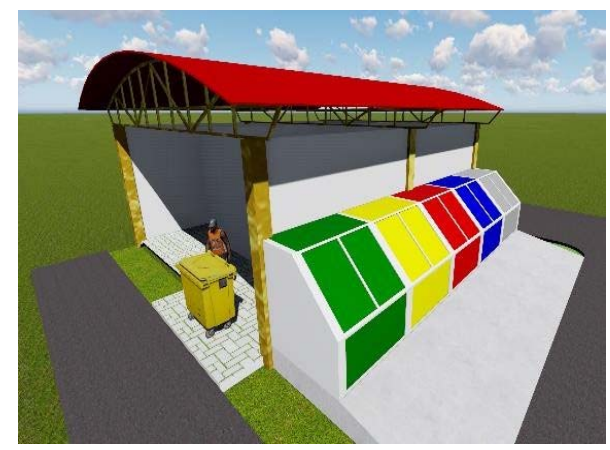

Gambar 23. Gedung pengelolaan sampah

Sumber : Analisa Penulis, 2019

Olahraga sangat penting bagi kesehatan penghuni rusun, karena itu disediakan tempat kebugaran pada kawasan rusun. Masyarakat umum dapat menggunakan fasilitas komersil ini. Aktivitas yang dilakukan pada gedung fitness yaitu olahraga (bergerak) dan terdapat alat- alat gym yang membutuhkan ruangan yang luas, karena itu gedung fitness menggunakan struktur bentang lebar

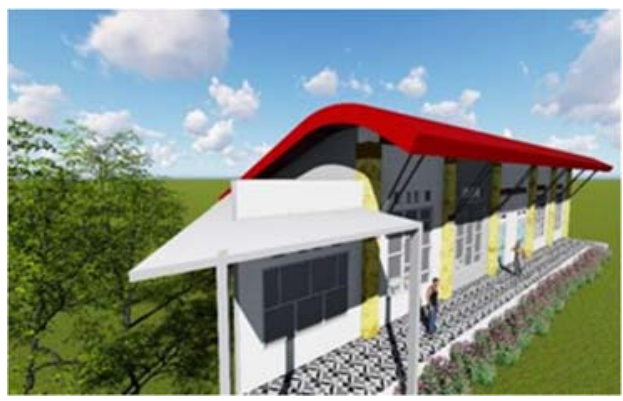

Gambar 24. Perspektif gedung fitness Sumber : Analisa Penulis, 2019 


\section{Simpulan}

Rusunami merupakan salah bangunan yang perencanaannya memiliki tingkat komplekitas yang tinggi. Selain mewadahi kebutuhan penghuni juga harus mampu mewadahi kenyamanan peghuni. Konsep Green Architecture yang diterapkan cukup mampu mengatasi kenyaman penghuni dan kebutuhan penghuni. Selain dari penghematan energi dan air, juga dapat menciptakan kenyamann bagi penghuni dengan menerapkan desain arsitektural yang mearik dan bermanfaat dalam upaya mencapai kenyaman secara termal.

\section{Referensi}

GBCI. ,2019. Green Building Council Indonesia. Accessed $\quad$ Maret 20, 2019.

Rustam, Hakim. 2012. Komponen Perancangan Arsitektur Lansekap. Jakarta: PT. Bumi Aksara.

Hariadhi. 2017. Wikipedia.Org.

Hendrix Van, DKK. ,2017. "Pola Pemanfaatan Ruang Bersama Pada Rusun Jatinegara Barat." Jurnal Arsitektur, Bangunan, \& Lingkungan 137. Accessed April 8, 2019. https://media.neliti.com/.../185918-ID- pola-pemanfaatan-ruang-bersama-pada- rusu.pdf.

KPPR. ,2016. Pengelola Rusunawa. Jakarta Patent PU-JICA:2007:21. Desember.

Muhammad Ali Sodik, DKK. ,2015. In Dasar Metodologi Penelitian. Yogyakarta: Literasi Media Publishing.Palembang, Portal Resmi Pemerintah Kota.,2016. Geografis Kota Palembang. Accessed April 1. 2019.

PMPU. ,2008. Pedoman Penyediaan dan Pemanfaatan Ruang Terbuka Hijau di Kawasan Perkotaan. Indonesia Patent Nomor: 05/PRT/M/2008.

Pratama, Raden Prabowo Yoga. ,2015. "Analisis Pemanfaatan dan Keberadaan Rusunawa di Bantaran Kali Code Kota Yogyakarta." Accessed Maret 26, 2019.

Riantiza Avesta, DKK. ,2017. "Strategi Desain Bukaan terhadap Pencahayaan Alami."

Rekayasa Hijau 126-128. Accessed April 8, 2019. lib.itenas.ac.id/kti/wpcontent/uploads/2018/02/RekayasaHijau_R iantiza.pdf.

RTRW. ,2012-2023. "Pemerintah Kota Palembang." Accessed Maret 25, 2019. tataruangpertanahan.com/regulasi/pdf/perd a/rtrw/.../kota_palembang_15_2012.pdf.

https:/jurnal.unpand.ac.id/index.php/dinsai n/article/download/90/87.

Sugiyono, 2006. Teknik Analisis Data. Accessed Juli 23, 2019. 